\title{
Variability in transport of fish eggs and larvae. III. Effects of hydrodynamics and larval behaviour on recruitment in plaice
}

\author{
Loes J. Bolle ${ }^{1, *}$, Mark Dickey-Collas ${ }^{1}$, Jan K. L. van Beek ${ }^{2}$, Paul L. A. Erftemeijer ${ }^{2}$, \\ Johannes IJ. Witte ${ }^{3}$, Henk W. van der Veer ${ }^{3}$, Adriaan D. Rijnsdorp ${ }^{1}$ \\ ${ }^{1}$ Wageningen IMARES - Institute for Marine Resources \& Ecosystem Studies, PO Box 68, 1970 AB IJmuiden, The Netherlands \\ ${ }^{2}$ DELTARES (formerly Delft Hydraulics), PO Box 177, 2600 MH Delft, The Netherlands \\ ${ }^{3}$ Royal Netherlands Institute for Sea Research (NIOZ), PO Box 59, 1790 AB Den Burg, The Netherlands
}

\begin{abstract}
Transport of plaice eggs and larvae in the southern North Sea was modelled using a finite-volume advection-dispersion model with high spatial and temporal resolution. Hydrodynamic forcing was based on actual river discharge and meteorological data for a 7 mo period in the winter and spring of 1989 and 1996 to 2003. Egg and larval development was linked to temperature and each developmental stage had its own physical and behavioural properties. Two hypotheses on transport mechanisms in the late larval stages were compared: passive drift versus selective tidal stream transport (triggered by environmental cues). Modelled larval stage durations closely corresponded to empirical estimates based on otolith daily ring counts. Close correspondence was also observed between model results and survey data on settlement in the western Wadden Sea, especially for the abundance of the strong 1996 year-class and the early settlement of the 2002 year-class. Transport patterns and the proportion of larvae reaching inshore nurseries varied substantially between years. Recruitment was negatively correlated with the distance over which eggs and larvae were transported, probably because of a breakdown in connectivity between spawning and nursery areas with increased transport rates. In conclusion, meteorologically driven variability in the hydrodynamics of the southern North Sea greatly affects the transport patterns of plaice eggs and larvae and may play an important role in determining recruitment variability and spatial connectivity.
\end{abstract}

KEY WORDS: Biophysical model - Hydrodynamic transport - Larval behaviour - Interannual variability $\cdot$ Connectivity $\cdot$ Recruitment $\cdot$ Pleuronectes platessa $\cdot$ North Sea

\section{INTRODUCTION}

The shallow coastal waters of the North Sea, and the Wadden Sea in particular, are important nursery areas for plaice (Zijlstra 1972, van Beek et al. 1989). Adults spawn offshore (Harding et al. 1978, van der Land 1991, Taylor et al. 2007) and eggs and larvae are transported towards the nursery areas by a combination of passive transport and selective tidal transport (Talbot 1977, Rijnsdorp et al. 1985). After metamorphosis, post-larvae settle in shallow coastal waters and on tidal flats in the estuaries (van der Veer 1986).
Year-class strength in plaice appears to be determined during the pelagic egg and larval stages, but the processes that generate recruitment variability are not fully understood. Relative year-class strength is set by the time the metamorphosing larvae reach the coastal nurseries for North Sea plaice (Bannister et al. 1974, van der Veer 1986), or shortly thereafter for Irish Sea plaice (Nash \& Geffen 2000). Density-dependent processes within nursery areas dampen the variability generated during the pelagic phase. This may play an important role in some nursery areas (Irish Sea, Nash \& Geffen 2000), but in the Wadden Sea, which is the most 
important nursery area for North Sea plaice (Zijlstra 1972), density-dependent mortality only fine-tunes recruitment variability, and the main factors driving variations in recruitment occur prior to the juvenile life-phase (van der Veer 1986, van der Veer et al. 2000).

Several hypotheses have been postulated on the factors causing recruitment variability during the egg and larval stages. Cold winters often produce strong yearclasses (van der Veer \& Witte 1999, Fox et al. 2000), and low egg mortality is associated with low seawater temperatures (Harding et al. 1978, Dickey-Collas et al. 2003). These low temperatures may also reduce larval mortality due to lower predator activity or to an improved match between the production cycles of larvae and their food (Cushing 1972, Leggett \& Deblois 1994); however, this may be offset by slower development of the larvae (Pepin 1991). Finally, variations in transport of larvae to coastal nursery grounds may contribute to variations in recruitment success (Nielsen et al. 1998, van der Veer et al. 1998).

In the present study we examined interannual variability in plaice egg and larval transport in the southern North Sea. We focused on the role of transport in determining recruitment variability and connectivity between spawning and nursery grounds. Furthermore, as some uncertainty exists on the extent and timing of tidally synchronised behaviour, we also examined the effect of larval behaviour on transport success. Egg and larval transport was modelled using a 3Dhydrodynamic model and an Eulerian transport model coupled with mathematical definitions of larval behaviour and development. The hydrodynamic model was forced using actual (spatially and temporally varying) river discharge and meteorological data for the period December to July for 9 different years. Model results were compared to empirical data on (1) stage duration (otolith daily ring counts), (2) larval immigration patterns in spring in the western Wadden Sea, and (3) geographic distribution patterns of juveniles in autumn. Finally, we compared modelled transport patterns to virtual population analysis (VPA) estimates of recruitment.

\section{DATA AND METHODS}

Hydrodynamic model. Hydrodynamic modelling was done with Delft3D-FLOW (Roelvink \& van Banning 1994, Lesser et al. 2004). The model incorporates a large number of processes, such as wind shear, wave forces, tidal forces, density-driven flows, stratification, atmospheric pressure changes, air temperature and the exposure and inundation of intertidal flats. Flow equations were solved on a curvilinear grid consisting of 8710 computational elements (Fig. 1, Roelvink et al.
2001). The vertical resolution of the model was 10 water layers using a sigma-coordinated approach (i.e. proportional to water depth, Stelling \& van Kester 1994). Hydrodynamic transport was computed using detailed bathymetry and open boundary forcing based on tidal constituents. The model was forced using meteorological data from the High Resolution Limited Area Model (HIRLAM, Royal Dutch Meteorological Service [KNMI]), which comprised 2 horizontal wind velocity components (at $10 \mathrm{~m}$ above mean sea level) and other atmospheric variables such as air pressure and temperature, archived every $6 \mathrm{~h}$. The freshwater discharges from 18 rivers were included in the model; 7 of these discharges varied temporally (daily averages) and 11 were constant (based on long-term averages) (see Erftemeijer et al. 2009, this volume). The model was run for the period 1 December to 1 July in 9 years (1988-1989 and 1995-1996 to 2002-2003). Water temperature and salinity were calculated within the hydrodynamic model. The model was calibrated with a focus on reproduction of the tidal water levels and validated by verification of residual flows and salinity patterns (Erftemeijer et al. 2009). Output from the hydrodynamic model was used as input for the transport model. The output was aggregated into $1 \mathrm{~h}$ time steps and vertically aggregated into 2 water layers (lower $4 \%$ and upper $96 \%$ of the water column) to decrease the size of the output files. Vertical aggregation is justified for the southern North Sea because of high vertical mixing rates (see below). Spatial aggregation in the horizontal dimension was not applied.

Transport model. Transport of fish eggs and larvae was modelled using Delft3D-WAQ (Postma 1988). This model calculates concentrations of substances (i.e. eggs and larvae) for each time-step as a function of the initial concentrations (reflecting spawning activity), advective and dispersive transport and biological characteristics and processes (e.g. development rates). Delft3D-WAQ is an Eulerian model based on the finite-volume method (i.e. multiplication of fluxes with concentrations to obtain masses across internal and external boundaries). The actual water system is represented within Delft3D-WAQ by means of computational elements (segments). The flow between segments is derived from the hydrodynamic model (Delft3D-FLOW). We opted for a finite-volume method rather than a particle tracking method mainly because of practical reasons: the (existing) Delft3D-WAQ model allowed great flexibility in defining biological characteristics and processes; the domain decomposition used in the companion paper (Erftemeijer et al. 2009) has not yet been implemented in particle tracking models. Furthermore, our focus was on mid-field and far-field effects rather than sub-grid resolution and for this (in principle) the same transport patterns can be 


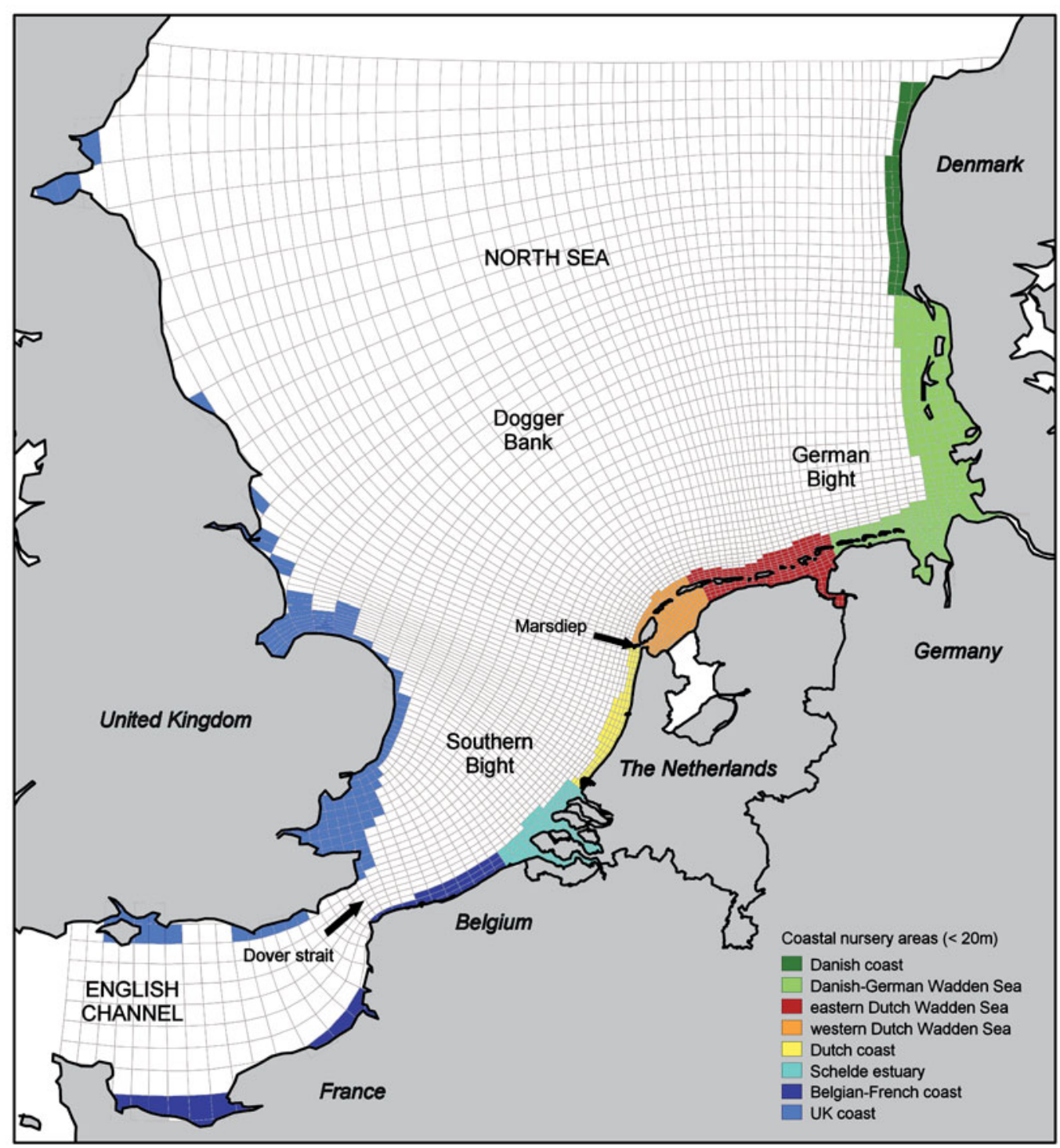

Fig. 1. Modelled area in the North Sea and eastern English Channel showing the model grid and coastal nursery areas used to estimate transport success

obtained using both finite-volume and particle tracking methods. A disadvantage of the finite-volume method is that it does not allow an individual-based approach. To overcome this disadvantage, different substances were modelled representing different cohorts (i.e. originating from different spawning grounds), with each cohort having their own stage development and as such their own physical and behavioural properties.

Horizontal dispersion. The transport model only consisted of 2 water layers and therefore does not include dispersion due to vertical velocity shear and vertical mixing. To compensate for this, extra horizontal diffusion was added. This issue received detailed attention in calibration studies on nutrient dynamics in the Dutch coastal zone (Nolte et al. 2005), where it was found that a dispersion coefficient of $100 \mathrm{~m}^{2} \mathrm{~s}^{-1}$ provided the best approximation for horizontal dispersion in a (virtually) 2D model.

Spawning. For plaice, the location of the spawning grounds is well documented. A simplification of the egg distribution in the southern North Sea as published by Harding et al. (1978) was used as input (initial condition) for the model (Fig. 2). Spawning in the German Bight, off the Danish coast and in the western parts of the North Sea (Harding et al. 1978, Taylor et al. 2007) were not included in the model. The main focus of the present study was on the Southern Bight spawning ground, because it is the most important contributor to the nursery grounds in the Dutch Wadden Sea for 


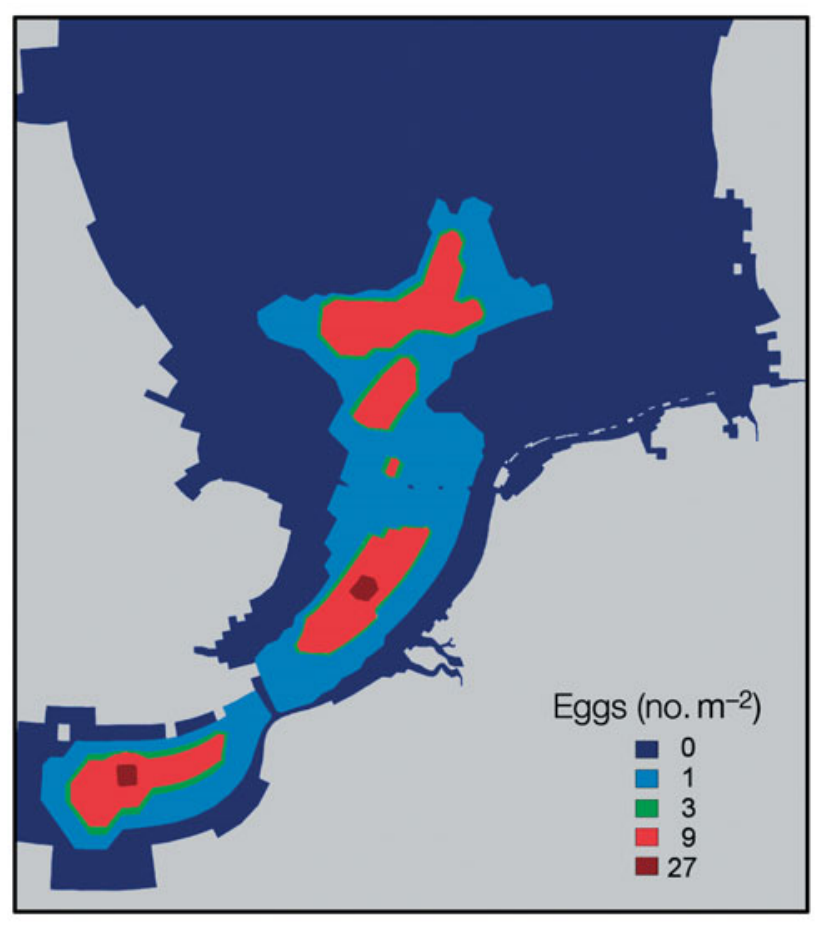

Fig. 2. Pleuronectes platessa. Release areas of eggs reflecting the spawning grounds of plaice in the eastern English Channel, Southern Bight and south of the Dogger Bank (after Harding et al. 1978)

which detailed information is available on larval immigration, and because the transport routes are within the area in which the model has high spatial resolution. All 3 spawning grounds combined were only used as input for the comparison with survey data on the spatial distribution of juveniles (Demersal Fish Survey, DFS).

Spawning commences in the English Channel in December and occurs progressively later further north. Spawning in the Southern Bight lasts 2 to 3 mo with peak spawning in mid-January. Peak spawning occurs approximately 1 mo earlier in the eastern English Channel and 1 mo later in the Dogger Bank region (Harding et al. 1978, Heessen \& Rijnsdorp 1989, van der Land 1991). Egg and larval transport was modelled assuming a single event of spawning on 15 January in the Southern Bight, 15 December in the eastern English Channel and 15 February in the Dogger Bank region.

Development of eggs and larvae. In the model, 5 developmental stages were distinguished based on different behavioural and physical traits in relation to transport.

Stage 1: Passive pelagic transport of eggs distributed homogeneously over the whole water column. The top 9 water layers of the hydrodynamic model were aggregated in the transport model. Justification for this is that vertical mixing in the southern North Sea is high and eggs are found throughout the water column, despite their positive buoyancy (Coombs et al. 1990, Sundby 1991).

Stage 2: Passive pelagic transport of larvae as in Stage 1. The distinction between eggs and pelagic larvae was made to facilitate growth parameter setting and testing.

Stage 3: Passive demersal transport (DEM) of metamorphosing larvae. Stages 3 and 4 were defined as alternatives for the behaviour of larvae after the onset of metamorphosis. In Stage 3, the larvae move to the bottom water layer (bottom $4 \%$ of water column) and are transported passively. Strictly speaking the term demersal is correct, but for flatfish it may cause confusion with the period after settlement. For the purpose of the present study, demersal was defined as near (bottom water layer) but not on the seabed.

Stage 4: Selective tidal stream transport (STST) of metamorphosing larvae. In Stage 4, larvae exhibit tidally synchronised behaviour, i.e. they stay on the seabed with ebb and move into the water column (bottom water layer) with flood. In the present study, this behaviour was related to salinity differences between ebb and flood, but the model also allowed it to be directly related to the direction of the currents. Thresholds for depth or salinity differences could be used to limit the area in which STST occurs; here we used a depth threshold.

Stage 5: Transport after metamorphosis is completed. In Stage 5, juveniles either continue to exhibit the behaviour of the previous stage, or stay on the seabed at the location they have reached (thus simulating settlement). In the present study, settlement was simulated after an assumed period of additional transport exhibiting behaviour as in the previous stage (Stage 3 or 4). The model also allowed settlement to be related to area, i.e. no further transport if a pre-defined nursery area had been reached.

Published and unpublished data on the duration of egg and/or larval stages, obtained from laboratory experiments, larval day-ring analyses and peak densities by egg stage, were used to estimate growth parameters (Table 1). These data were reworked to calculate parameters for an exponential regression: $\ln (D)=$ $\alpha+\beta T$, in which $D$ is stage duration (d) and $T$ is temperature $\left({ }^{\circ} \mathrm{C}\right)$. As laboratory studies tend to underestimate development rates (Russell 1976), the highest development rate for each stage was chosen as default setting for the model, except for the pelagic larval phase (model Stage 2). The larval duration estimates presented by Hovenkamp (1991) were very low, which (according to the author) may be due to an underestimation of the yolk-sac phase. Therefore, the default growth parameters for model Stage 2 were set to fit the 
Table 1. Pleuronectes platessa. Stage duration in relation to temperature based on published and unpublished data. Data have been reworked to fit an exponential regression, $\ln (D)=\alpha+\beta T$ in which $D$ is stage duration (d) and $T$ is temperature, if $\alpha$ and $\beta$ estimates are given. (-) no data

\begin{tabular}{|c|c|c|c|c|c|c|c|c|c|c|c|}
\hline \multirow[t]{2}{*}{ Model } & \multirow[t]{2}{*}{ Source } & \multirow[t]{2}{*}{$\alpha$} & \multirow[t]{2}{*}{$\beta$} & \multicolumn{8}{|c|}{ - Stage duration $(\mathrm{d})$ if $T\left({ }^{\circ} \mathrm{C}\right)=$} \\
\hline & & & & 5 & 6 & 7 & 8 & 10 & 11 & 12 & Unknown \\
\hline \multicolumn{12}{|l|}{ Stage 1} \\
\hline (eggs, egg stages $1-5$ & Apstein (1909) & 3.70 & -0.11 & 24 & 21 & 19 & 17 & 14 & 13 & 11 & \\
\hline according to Ryland & Ryland \& Nichols (1975) & 3.95 & -0.15 & 25 & 21 & 18 & 16 & 12 & 10 & 9 & \\
\hline \multirow{3}{*}{ \& Nichols 1975) } & Talbot (1977) & 3.94 & -0.15 & 25 & 21 & 18 & 16 & 12 & 10 & 9 & \\
\hline & Harding et al. (1978) & 3.64 & -0.10 & 23 & 21 & 19 & 17 & 14 & 13 & 12 & \\
\hline & Fox et al. (2003) (Expt 4) & - & - & - & 20 & - & 15 & 11 & - & - & \\
\hline Default model settings & & 3.95 & -0.15 & 25 & 21 & 18 & 16 & 12 & 10 & 9 & \\
\hline \multirow{8}{*}{$\begin{array}{l}\text { Stage } 2 \\
\text { (pelagic larvae, } \\
\text { larval stages 1-3 } \\
\text { according to Ryland } \\
\text { 1966) }\end{array}$} & & & & & & & & & & & \\
\hline & Dannevig (1897) & - & - & - & - & - & - & - & - & - & 35 \\
\hline & Ryland (1966) & - & - & - & - & 49 & 49 & - & - & - & \\
\hline & Talbot (1977) & 5.43 & -0.18 & 91 & 76 & 63 & 52 & 36 & 30 & 25 & \\
\hline & Harding et al. (1978) & - & - & - & 70 & 70 & - & - & - & - & \\
\hline & Hovenkamp (1991) & - & - & 49 & - & 36 & 30 & - & - & - & \\
\hline & A. J. Geffen unpubl. data & - & - & - & - & - & - & 33 & - & - & \\
\hline & Otolith data $1997 \& 2001$ & - & - & - & - & 50 & 47 & - & - & - & \\
\hline Default model settings & & 5.00 & -0.15 & 70 & 60 & 52 & 45 & 33 & 29 & 25 & \\
\hline \multirow{7}{*}{$\begin{array}{l}\text { Stage } 3 \text { or } 4 \\
\text { (metamorphosing larvae, } \\
\text { larval stages } 4-5 \\
\text { according to Ryland } \\
\text { 1966) }\end{array}$} & & & & & & & & & & & \\
\hline & Dannevig (1897) & - & - & - & - & - & - & - & - & - & 10 \\
\hline & Ryland (1966) & - & - & _- & _- & _- & - & 17 & 17 & - & \\
\hline & Talbot (1977) & 4.53 & -0.16 & 41 & 35 & 30 & 25 & 18 & 16 & 13 & \\
\hline & Harding et al. (1978) & - & - & - & 34 & 34 & - & - & - & - & \\
\hline & A. J. Geffen unpubl. data & _- & - & - & - & - & - & 5 & - & _- & \\
\hline & Otolith data 1997 \& 2001 & - & - & - & - & 9 & 9 & - & - & - & \\
\hline Default model settings & & 3.40 & -0.15 & 14 & 12 & 10 & 9 & 7 & 6 & 5 & \\
\hline Total duration & & & & 109 & 94 & 81 & 69 & 51 & 44 & 38 & \\
\hline
\end{tabular}

stage durations based on part of the otolith data available for the present study (see 'Data and methods') and unpublished data provided by A. J. Geffen (University of Bergen, Norway). Stage duration was recalculated for each consecutive time step in the model based on an update of the mean temperature experienced during this stage.

Larval behaviour. Selective tidal stream behaviour has been reported for plaice larvae immigrating into estuaries by Creutzberg et al. (1978) and Rijnsdorp et al. (1985), but these findings were debated by Bergman et al. (1989). Recent modelling studies argued that without selective tidal behaviour, plaice larvae do not reach the inshore nursery areas (de Graaf et al. 2004, Fox et al. 2006). It is uncertain when exactly plaice start to exhibit tidally synchronized behaviour and some plasticity in the development of this behaviour is expected (Gibson et al. 1996, Fox et al. 2006). Therefore, 2 alternative hypotheses for the transport mechanism in the late larval and early juvenile stages were examined: DEM versus STST.

Pilot runs were carried out in which the larvae were programmed to stay on the seabed during ebb and instantaneously move up into the water column (bottom water layer only) during flood. Similar approaches were taken by Fox et al. (2006) who linked the direction of vertical swimming to the direction of the current, and de Graaf et al. (2004) who linked an instantaneous change in the vertical distribution to decreasing or increasing water levels. Orientation of larvae towards the coast is presumably achieved in response to one or several environmental cues related to the tidal flux. Sole can sense pressure differences (MacquartMoulin et al. 1989) and flounder can sense salinity differences (Z. Jager unpubl. data). Boehlert \& Mundy (1988) reviewed studies on recruitment into estuaries by species which spawn offshore and they presented several cases in which clear responses to salinity changes were observed. Little is known about the cues which plaice larvae use for orientation during STST. In the final runs of the present study, we assumed that salinity differences between ebb and flood tide triggers vertical migration, i.e. the larvae stay on the seabed when salinity decreases (due to fresh water runoff in the ebb tide) and move up into the water column when salinity increases. This approach worked well in coastal waters but resulted in a very patchy distribution pattern further offshore due to small salinity differences combined with low temporal resolution of the salinity data (i.e. $1 \mathrm{~h}$ ). Therefore, the area in which 
STST occurs was restricted by setting an arbitrary maximum depth boundary at $30 \mathrm{~m}$.

Some information exists indicating that recently metamorphosed juveniles do not settle until they have reached a suitable nursery area (Creutzberg et al. 1978, Rauck 1974), but no exact information is available on how long juveniles can survive if they do not settle. We (arbitrarily) assumed that transport can continue up to 1 mo after metamorphosis.

Analysis of model output. The model calculated concentrations of eggs and larvae in each water layer and on the seabed for each grid-cell and time step. These 3D concentrations were vertically aggregated (including larvae on the seabed) into numbers per square meter. Aggregated densities (no. $\mathrm{m}^{-2}$ ) were plotted as contour plots for specific moments in time and as time series for specific locations. Transport success was defined as the proportion of the total number spawned that arrived in a certain nursery area (Fig. 1) at the end of the transport phase. The underlying assumption was that larvae died if they failed to reach the coastal nursery areas in time. The model did not include mortality during the transport phase. Displacement quantified the net distance travelled by a cohort of larvae. For each day, the centre of the concentration was calculated and the distance from the spawning ground to this centre was defined as displacement. The sensitivity of the model to various assumptions and parameter settings was tested.

Comparisons with empirical data. The DFS is an ongoing survey carried out annually in September-October which covers the coastal and estuarine waters from the Schelde estuary to the Danish Wadden Sea. The survey targets juvenile flatfish by sampling shallow waters with a beam-trawl rigged with a fine-meshed net. Details on the survey design are presented in ICES (2006). The DFS provided information on the spatial distribution of 0-group plaice in autumn.

From 1993 to 2002, the abundance of 0-group plaice on a tidal flat in the western Wadden Sea (Balgzand) was surveyed once each fortnight between March and June, and from 1994 onwards otoliths were collected for day-ring analysis. These data provided information on (1) interannual variability in abundance and seasonal patterns of plaice entering the Wadden Sea, and (2) larval stage durations. The methodology and part of the data have been published previously (van der Veer \& Witte 1999, van der Veer et al. 2000). Data for 1996-2002 were included in the pre- sent study and the full time series is presented in van der Veer et al. (2009, this volume). Part of the day-ring data (1997 \& 2001) were included in Table 1 and contributed to the choice of model settings.

\section{RESULTS}

The present study focused on drift patterns in the early life-history stages of plaice. It is important to note that the model did not include egg or larval mortality during transport. Assumptions on mortality were only used to end the transport phase.

\section{Transport patterns}

Plaice eggs and larvae drifted with the residual currents in a northeasterly direction (Figs. $3 \& 4$ ). Plaice originating from the Southern Bight spawning ground populated nursery areas from the Schelde estuary to the Danish-German Wadden Sea and, in years with strong flows, they even reached the northern Danish coasts. The contribution of the English Channel spawning ground extended as far as the Schelde estuary and the Dutch coast, but was negligible in the Wadden Sea (Fig. 3). For the 9 years included in the present study, on average only $0.4 \%$ of plaice that were spawned in the eastern English Channel reached

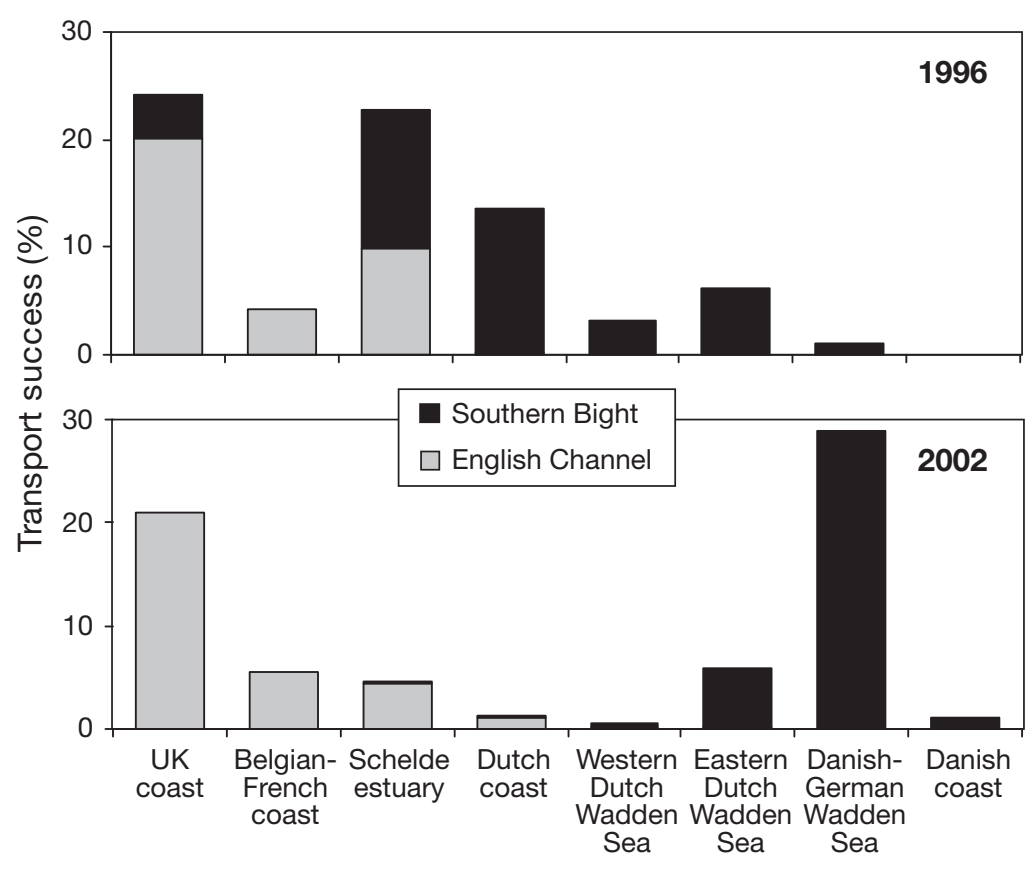

Fig. 3. Pleuronectes platessa. Transport success by region (percent of all larvae reaching specific nursery area) in 1996 and 2002 for plaice originating from spawning grounds in the eastern English Channel and Southern Bight assuming selective tidal stream transport in the late larval and early juvenile stages 

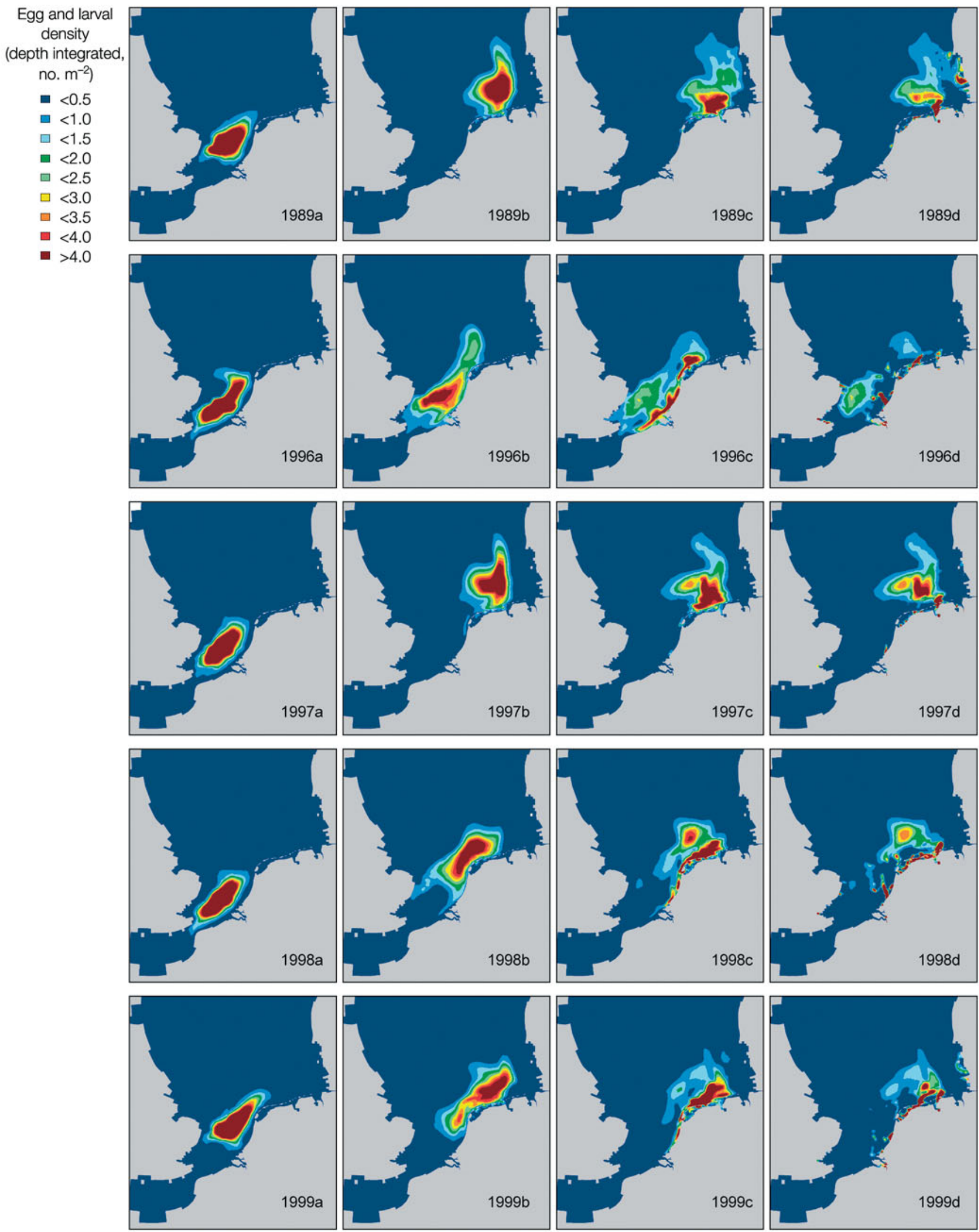

Fig. 4. Pleuronectes platessa. Geographic distribution of plaice originating from the Southern Bight spawning ground at the end of the (a) egg stage, (b) pelagic larval stage, (c) late larval and early juvenile stages if passive demersal transport is assumed, (d) late larval and early juvenile stages if selective tidal stream transport is assumed 

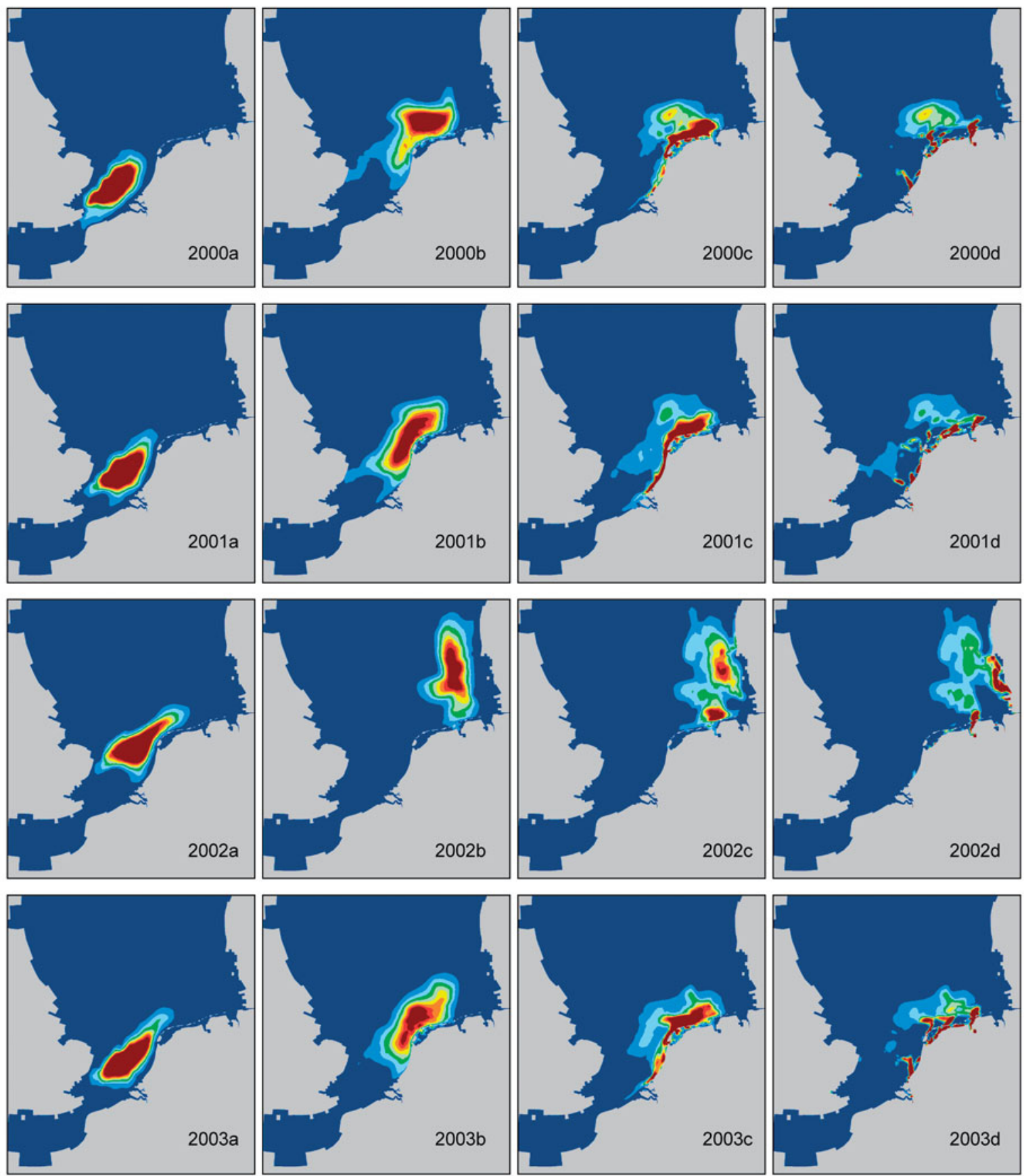

Fig. 4 (continued)

the Wadden Sea. Spawning in the Dogger Bank region was only included in the model runs in which all spawning grounds were combined for the comparison with DFS data on the spatial distribution of juveniles.

Substantial differences were observed among years. The northeasterly flow of eggs and larvae was extremely low in 1996 and high in 2002 (Figs. 3 to 5). These differences were mainly generated in the pelagic egg and larval phases (Fig. 4a,b). The pelagic phase ended after 74 to $86 \mathrm{~d}$, and by then the pattern of inter- annual variability in transport was established (Fig. 5). During the pelagic phase, larvae are transported along the coast and this displacement was related to residual currents (Fig. 4a,b). The direction of transport during the late larval and early juvenile phase was mainly cross-shore, i.e. larvae moved towards the coast from the position they had reached during the pelagic phase. Cross-shore transport was achieved by DEM, but it was more effective if the late larval and early juvenile stages exhibited STST (Fig. 4c,d). 


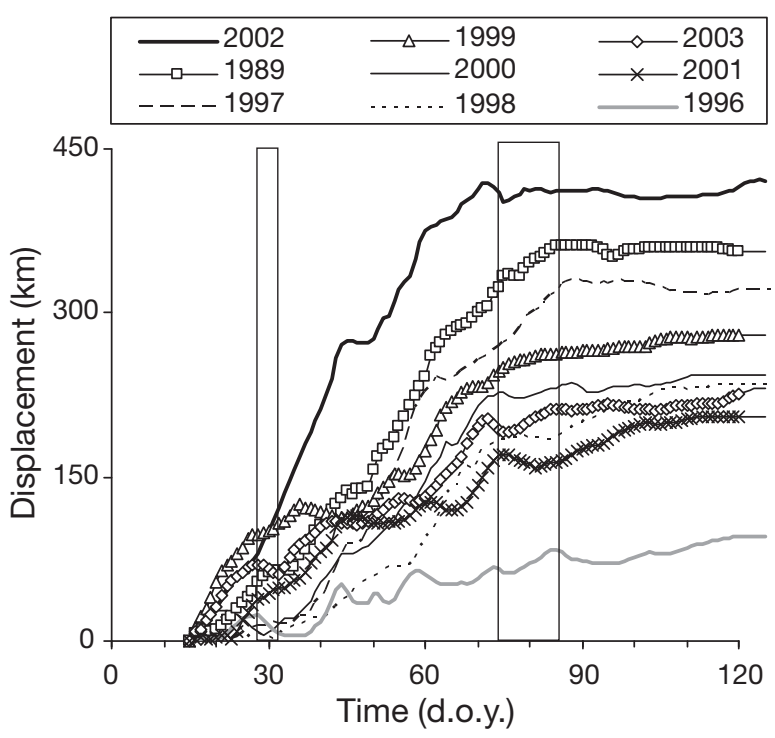

Fig. 5. Pleuronectes platessa. Displacement $(\mathrm{km})$ of the centre of concentration of plaice eggs and larvae as a function of time (day of year, d.o.y.). Rectangles indicate the interannual range of the end of the egg (left) and pelagic larval (right) stages. Egg and larval transport was modelled for plaice originating from the Southern Bight spawning ground assuming selective tidal stream transport in the late larval and early juvenile stages

Year-to-year variability was also evident in the transport success to all nursery areas combined (Table 2). Transport success did not appear to be related to the distance over which larvae were transported $\left(n=9, r^{2}=\right.$ $0.27, \mathrm{p}=0.15$ ). Transport success was highest in 2001 (average northeasterly flow) and lowest in 1997 (above average northeasterly flow). For the 9 years examined, the proportion of larvae (from the Southern Bight spawning ground) that reached the coastal nursery areas ranged from 21 to $53 \%$ if STST was assumed and from 8 to $33 \%$ if DEM was assumed (Table 2). Selective tidal stream behaviour resulted in a significant increase of the proportion of larvae that reached the coastal nurseries (ANOVA including year: $\mathrm{n}=9, \mathrm{r}^{2}=$ $0.98, \mathrm{p}<0.01)$.

\section{Sensitivity analysis}

The sensitivity of the model was explored for all parameter settings and model inputs (see Bolle et al. 2005); a summary of the results is presented in Table 3.

Timing of spawning affects transport success and geographic distribution of the larvae at the end of the transport phase. Earlier spawning results in lower transport success (Table 3a) and further transport of eggs and larvae along the coast in northeasterly direction (data not presented).
Sensitivity of the model to the range of development rates (Table 1) was tested. Differences in Stage 1 were negligible. Higher development rates in Stage 2 generally caused an increase in transport success (Table 3b). Lower development rates caused a decrease in transport success during Stage 2, which was compensated for by an increase in Stage 4. Lower development rates in Stage 2 prolonged the passive transport phase and therefore shifted the distribution of the larvae in northeasterly direction (data not presented).

The assumption of transport after metamorphosis clearly affected the transport success estimates; the

Table 2. Pleuronectes platessa. Percent of total number of plaice spawned in the Southern Bight that reached the coastal nursery areas for each year and both transport mechanisms. STST: selective tidal stream transport; DEM: passive demersal transport

\begin{tabular}{|c|c|c|}
\hline \multirow{2}{*}{ Year } & \multicolumn{2}{|c|}{ Transport mechanism (\%) } \\
\hline & STST & DEM \\
\hline 1989 & 34 & 13 \\
\hline 1996 & 41 & 24 \\
\hline 1997 & 21 & 8 \\
\hline 1998 & 42 & 24 \\
\hline 1999 & 39 & 24 \\
\hline 2000 & 45 & 27 \\
\hline 2001 & 53 & 33 \\
\hline 2002 & 37 & 11 \\
\hline 2003 & 47 & 25 \\
\hline
\end{tabular}

Table 3. Pleuronectes platessa. Sensitivity analyses for model settings on (a) spawning period, (b) development rates and (c) duration of transport after metamorphosis. Percent of total number of plaice spawned in the Southern Bight that reached the coastal nursery areas, assuming selective tidal stream transport in the late larval and early juvenile stages. See Table 1 for development rates

\begin{tabular}{|c|c|c|c|}
\hline \multirow[t]{2}{*}{$\mathbf{a}$} & \multicolumn{3}{|c|}{ - Model setting } \\
\hline & $\begin{array}{l}2 \mathrm{wk} \\
\text { earlier }\end{array}$ & $\begin{array}{l}\text { Peak spawning } \\
\text { (default) }\end{array}$ & $\begin{array}{l}2 \mathrm{wk} \\
\text { later }\end{array}$ \\
\hline 1989 & 31 & 34 & 35 \\
\hline 1996 & 35 & 41 & 40 \\
\hline 2000 & 36 & 45 & 47 \\
\hline b & $\begin{array}{l}\text { Higher rates } \\
\text { (Stage } 2 \text { only) }\end{array}$ & Default & $\begin{array}{l}\text { Lower rates } \\
\text { (Stages 1-4) }\end{array}$ \\
\hline 1989 & 38 & 34 & 51 \\
\hline 1996 & 47 & 41 & 55 \\
\hline 2000 & 36 & 45 & 50 \\
\hline $\mathbf{c}$ & $0 \mathrm{~d}$ & $30 \mathrm{~d}$ (default) & $60 \mathrm{~d}$ \\
\hline 1989 & 9 & 34 & 54 \\
\hline 1996 & 19 & 41 & 63 \\
\hline 2000 & 17 & 45 & 63 \\
\hline
\end{tabular}


proportion of larvae reaching coastal nursery areas strongly increased if the duration of transport in model Stage 5 was prolonged (Table 3c). As the direction of transport during this stage was mainly cross-shore, only slight changes in the geographic distribution were observed (data not presented). Furthermore, relative patterns of interannual variability were hardly affected by this assumption (Table 3c).

\section{Comparisons with empirical data}

\section{DFS}

The modelled abundance (total number) by nursery area at the end of the transport phase (April to May) was averaged for the 9 years included in the present study and compared to the mean abundance of 0 group plaice observed in the DFS in September to October (Fig. 6). Absolute numbers could not be compared because mortality was not included in the model. Relative patterns of distribution could be compared if (1) the spatial distribution did not change between April to May and September to October, (2) no spatial variability in mortality occurred within the nursery areas, and (3) all spawning grounds contributing to the nursery areas covered by the DFS were included in the model runs. Given these limitations to the comparison, the model tended to overestimate the number of larvae reaching the Schelde estuary, Dutch coast and eastern Wadden Sea, and to underestimate the number of larvae reaching the western Dutch Wadden Sea and Danish-German Wadden Sea (Fig. 6).

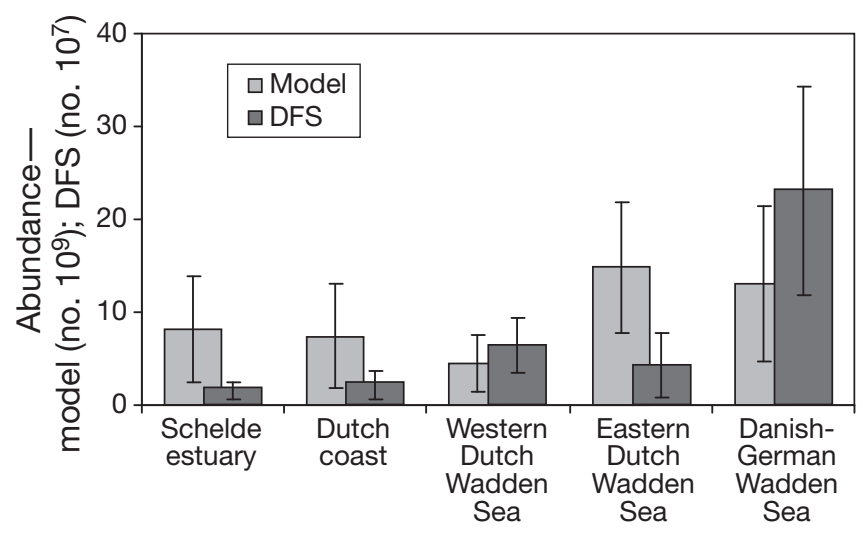

Fig. 6. Pleuronectes platessa. Mean abundance (total number) of 0-group plaice per region in April-May according to model simulations for all 3 spawning grounds combined assuming selective tidal stream transport in the late larval and early juvenile stages, and in September-October as observed in the Demersal Fish Survey (DFS). Error bars: SD of interannual variability. Only a relative comparison is possible because mortality was not included in the model simulations
Otolith data

In otoliths of juvenile plaice, the hatch ring, metamorphosis ring and daily increments can be discriminated (van der Veer et al. 2009). Otolith analyses thus provided an estimation of the duration between hatching and the onset of metamorphosis (model Stage 2) and between the onset of metamorphosis and catch date as recently settled juvenile (model Stage 3 or 4). Modelled and observed mean stage durations showed a close correspondence in all years (Fig. 7). The stage durations estimated for 1997 and 2001 could not be used for model validation as these data were used (combined with other data) to calibrate the growth model. Stage duration did not vary much between years according to the model simulations as well as the otolith data (see also van der Veer et al. 2009).

Tidal flat survey in the western Wadden Sea

The tidal flat survey in the western Wadden Sea provided estimates for the timing of settlement and the abundance at the time of settlement. Recently settled juveniles were distinguished from the rest of the 0-group based on length $(<15 \mathrm{~mm})$. The seasonal pattern in the catch rates (no. ha ${ }^{-1}$ ) of recently settled plaice was compared to modelled densities (no. $\mathrm{m}^{-2}$ ) at a model observation point in the Marsdiep Channel close to the survey area (Fig. 8). Only a relative comparison was possible because mortality was not included in the model. Field data and model simulations matched well in 7 of the 9 years, but in 1997 and 2000 the modelled time series showed 2 peaks, whereas the field data showed only 1 peak (approximately in between the 2 model peaks). This difference might be due to the fact that the model results were based on a single spawning event. If the period of larval supply is extended, smoothing of the seasonal distribution pattern can be expected, giving a better correspondence with the field data. For 2002, both the model simulation as well as the tidal flat survey suggested an

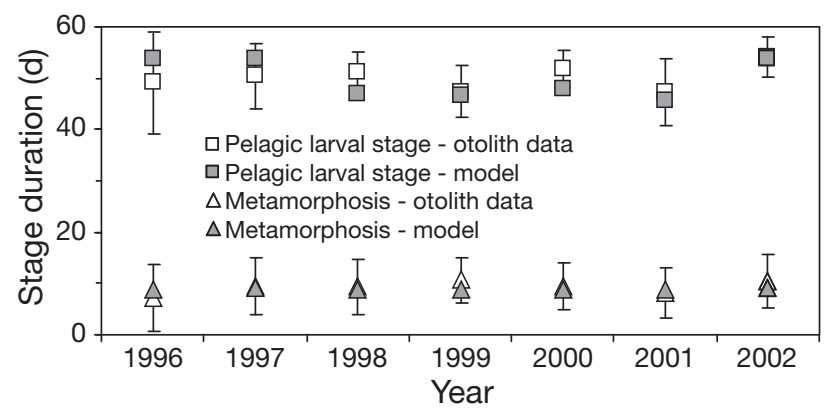

Fig. 7. Pleuronectes platessa. Duration (d) of the pelagic larval stage and metamorphosis according to model simulations and otolith day-ring data. Error bars: SD for the otolith data 

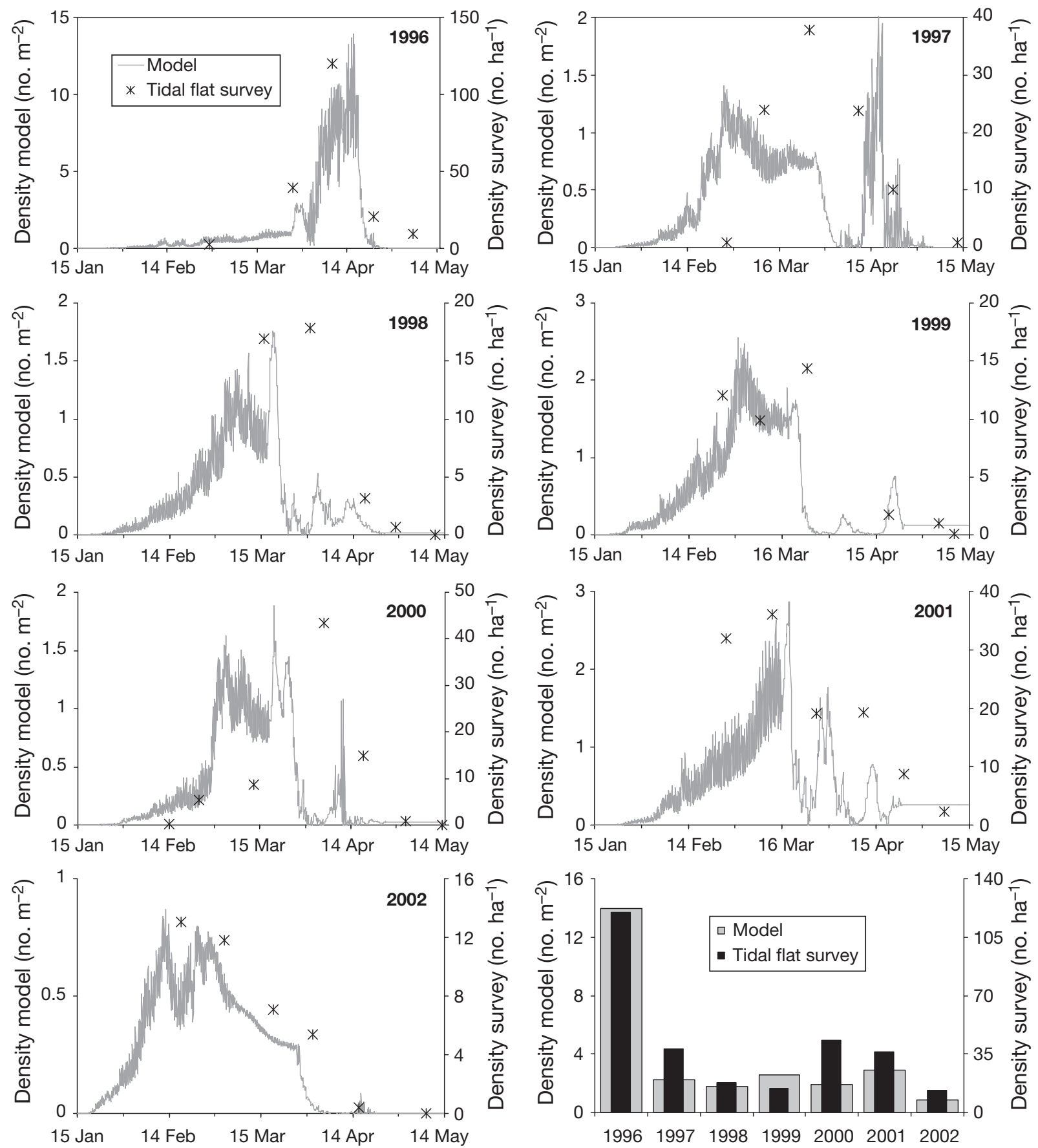

Fig. 8. Pleuronectes platessa. Density of just-settled plaice juveniles in the western Wadden Sea according to model simulations and survey data (tidal flat survey). Histogram (bottom right) shows the modelled and observed peak density in each year. Egg and larval transport was modelled for plaice originating from the Southern Bight spawning ground assuming selective tidal stream transport in the late larval and early juvenile stages. Only a relative comparison is possible because mortality was not included in the model simulations

extremely early arrival of plaice larvae in the western Wadden Sea.

The correspondence between observed and modelled interannual variability in the level of peak density was high based on the fact that both approaches estimated the abundance in 1996 to be much higher than in other years (Fig. 8, bottom right panel). Peak density in the tidal flat survey is considered to be an index for year-class strength (van der Veer et al. 2009). This index is highly correlated with modelled peak density $\left(\mathrm{n}=7, \mathrm{r}^{2}=0.91, \mathrm{p}<0.01\right)$, but the relationship was mainly driven by the 1996 results. 
Recruitment in relation to transport

The proportion of larvae reaching coastal nursery areas (transport success) increased with increased water temperatures (Fig. 9a) and, as stage duration is inversely related to temperature (Table 1), increased with decreased stage durations.

Transport parameters were correlated with VPA estimates (ICES 2008) of recruitment at age 1 (R) corrected
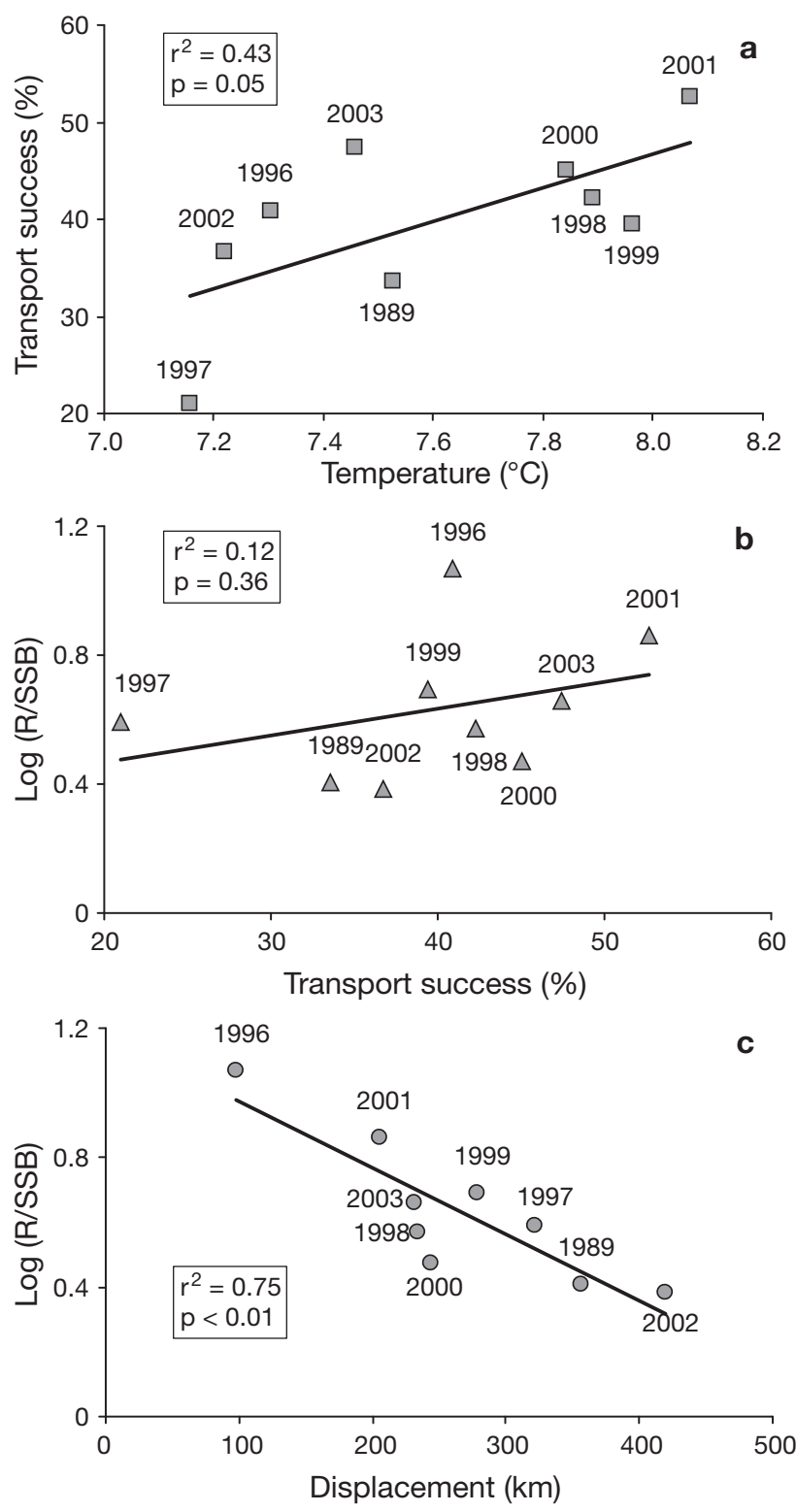

Fig. 9. Pleuronectes platessa. Correlations between (a) transport success (percent of larvae reaching nursery areas) and mean temperature experienced during transport, (b) $\log (\mathrm{R} / \mathrm{SSB})$ and transport success, where $\mathrm{R}$ is the virtual population analysis estimate $\left(\times 10^{3}\right)$ of recruitment at age 1 and SSB is spawning stock biomass (t) (ICES 2008), and (c) $\log (\mathrm{R} / \mathrm{SSB})$ and displacement of cohort during egg and larval transport for spawning stock biomass (SSB) by using $\log (\mathrm{R} / \mathrm{SSB})$ as the dependent variable. No significant relationship was observed between recruitment $(\log (\mathrm{R} / \mathrm{SSB}))$ and transport success (Fig. 9b). Recruitment significantly decreased with increased displacement (Fig. 9c).

\section{DISCUSSION}

\section{Model evaluation}

Spawning activity was simplified in the model. Egg production was fixed for all model runs, because annual egg production estimates are not available for plaice. In reality, fluctuations in egg production occur, reflecting variations in SSB (Heessen \& Rijnsdorp 1989, van Damme et al. 2009). The SSB of North Sea plaice has changed appreciably during the time span covered by the present study, but only a limited effect of these variations on recruitment is expected because of the absence of a clear stock-recruitment relationship (ICES 2008). Nevertheless, recruitment estimates have been corrected for SSB before correlating them with the transport parameters.

Spawning date varied by spawning ground but was fixed for all years. Although interannual variability in timing of spawning is considered to be small for plaice (Cushing 1990), maturity data showed that the timing of spawning is significantly related to ambient water temperature and will be advanced in warm winters (Teal et al. 2008). The sensitivity analyses indicated that earlier spawning resulted in lower overall transport success and larger distances over which the larvae were transported. It is unlikely that these differences in our model were caused by temperature-related variations in stage duration because water temperature varied little over the time span of the sensitivity analyses. These seasonal variations in transport pattern were driven by hydrodynamic variability related to weather conditions and, for the years examined, residual currents were stronger in the earlier part of the spawning period.

Duration of the egg and larval stages was determined by growth parameters and ambient temperature. Several studies on the duration of egg stages in relation to temperature presented similar results, but less has been published on the duration of larval stages and the estimates are wider apart (see references in Table 1). The choice of growth parameters for the larval phase had a noticeable effect on stage duration and hence on the transport patterns. The close correspondence between modelled and observed larval stage durations (for the years not included in the calibration) corroborated the choice of growth parameters. Stage duration was modelled as a function of temperature 
but it may also vary over the years due to differences in food conditions (van der Veer et al. 2009).

No doubt exists about the assumption that plaice larvae end their pelagic life-style at the onset of metamorphosis, but uncertainty does exist on the duration of transport after metamorphosis is completed. Recently metamorphosed juveniles probably continue to use selective tidal (or passive demersal) transport until they have reached a suitable nursery area. Gibson (1973) showed that on the more exposed coasts of the UK plaice appear to settle in deeper water and then move onshore into shallower water. The decision to stay or move on can be determined by food availability (Creutzberg et al. 1978) or by predation pressure (Gibson et al. 2002). It is uncertain how long larvae and/or juveniles can survive in their search for a suitable nursery ground. Anecdotal information suggests that recently metamorphosed juveniles can survive for at least some weeks and maybe up to $30 \mathrm{~d}$ without food at temperatures of about $10^{\circ} \mathrm{C}$ (authors' pers. obs.). The delayed appearance of cohorts of juveniles in the German Bight suggests that the period of transport after metamorphosis may even be longer (Rauck 1974). The sensitivity analyses clearly showed that if the period of transport after metamorphosis is prolonged, more larvae reach the inshore nurseries.

The western Wadden Sea survey showed interannual variability in timing of settlement, whereas the accompanying otolith data suggested that on average plaice settle at approximately the same age every year. This difference can partly be explained by interannual variability in timing of spawning in the Southern Bight (or interannual variability in which part of the cohort survives during transport). The spawning date corresponding with the date of peak settlement can be back-calculated based on observed larval stage duration and estimated egg stage duration. For all years except 2002, the difference between back-calculated spawning date and peak spawning in the Southern Bight was relatively small $(-8$ to $+10 \mathrm{~d})$ compared to the duration of spawning. But the back-calculated spawning date for peak settlement in 2002 was midDecember, which is unlikely for the Southern Bight spawning population (Harding et al. 1978, van der Land 1991). An alternative explanation for the early arrival of plaice in 2002 is that they originated from the English Channel spawning ground. However, this explanation was not supported by the model results. Firstly, the modelled transport from the eastern English Channel to the western Wadden Sea was negligible, even in years with strong northeasterly drift such as 2002. Secondly, the model results for the Southern Bight in 2002 closely corresponded to the otolith and survey data, thus showing the same discrepancy between stage duration and timing of arrival in the western Wadden Sea. At this stage, no conclusive explanation can be given for the 2002 findings. Either the day-ring data are incorrect and the larvae originated from the Southern Bight spawning ground, or the model results are incorrect and the larvae originated from the English Channel spawning ground (in which case the close match between the Southern Bight model results and the survey data is spurious).

\section{Larval behaviour}

At the onset of the metamorphosis, larvae increase in mass (Power et al. 2007) and disappear from pelagic offshore catches of ichthyoplankton. Plaice larvae do not appear in inshore catches until the late larval stages (Creutzberg et al. 1978). Selective tidal stream behaviour has been reported for plaice larvae in coastal waters (Rijnsdorp et al. 1985), but this conclusion was debated by Bergman et al. (1989) based on a comparison between suspended matter and larvae in the water column during different tidal phases. Jager (1999) adopted this approach and concluded that flounder larvae use STST to enter estuaries. In sole, no evidence for behavioural selection of onshore currents was found in the larval stages (Koutsikopoulos et al. 1991), but in recently settled juveniles the diurnal vertical migrations may develop into semi-diurnal patterns resulting in onshore movement (Champalbert \& Koutsikopoulos 1995).

We have explored the implications of 2 alternative assumptions on behaviour during the late larval stages: passive transport in the bottom water layer (DEM) or STST. Evidently, introducing STST in the model will increase the proportion of larvae that reaches the inshore nursery areas. The question is whether such behaviour is essential for settlement success. Fox et al. (2006) modelled larval transport in the Irish Sea and argued that tidal behaviour is a key factor, because with passive drift alone the larvae failed to reach the nursery grounds in significant numbers. Similar results were found by de Graaf et al. (2004) for the North Sea; virtually none of the larvae that were spawned in the Southern Bight reached the Wadden Sea nursery area by passive drift. In the present study the proportion of larvae which successfully reached the inshore nursery areas increased by approximately a factor 2 if STST was assumed. The difference with passive drift was much smaller than previously modelled (de Graaf et al. 2004, Fox et al. 2006) for 2 reasons. Firstly because of the way we defined STST, which is more realistic but less effective: STST was restricted to coastal waters and linked to salinity differences. Secondly because of the assumption that late larval stages move into the bottom water layer. Along the Dutch coast a residual 
cross-shore current occurs in the bottom water layer, which results in an onshore movement of passively transported particles (Joordens et al. 2001). This phenomenon has been called the 'Texel gate' in the past (Cushing 1972). Seaward flow in surface layers and landward flow at depth is typical for coastal waters with freshwater discharge (Werner et al. 1997). The results of the present study clearly showed that, although STST increases transport success, plaice larvae can reach the inshore nursery areas by passive drift alone. These results do not rule out the necessity of STST for settlement success, but it can be concluded that STST is less pivotal than previously assumed.

\section{Interannual variability}

The present study focused on the role of transport in determining recruitment variability and connectivity between spawning and nursery grounds. Model simulations showed large interannual variations in egg and larval transport patterns, mainly caused by meteorologically driven variability in the along-shore residual currents during the pelagic offshore phase of transport. Herring, an offshore spawner like plaice, also showed large interannual variability in transport patterns (Dickey-Collas et al. 2009, this volume), whereas sole, a coastal spawner, showed much less variation in transport patterns (Bolle et al. 2005).

Increased temperature positively affected transport success through decreased duration of the pelagic egg and larval stages. Hyder \& Nash (1998) came to similar conclusions based on a fundamentally different model: their model included mortality but did not include hydrodynamic transport. Temperature was the most important driving force in their model, whereas in our model the contribution of temperature was small and year-to-year variability was mainly caused by hydrodynamic variability. The results for 1996 and 2002 were compared to disentangle the effect of temperature (stage duration) and water movement in our model: larval dispersal differed extremely between these 2 years, while stage duration was almost identical, which indicated that water movement was by far the most important of these 2 factors. The role of temperature is expected to become increasingly more important if more biological processes (e.g. mortality) are included in the model.

Modelled temperatures, and even more so the mean temperature experienced by a cohort of larvae during transport, showed less interannual variation than would be expected based on coastal surface water temperatures (www.waterbase.nl). Modelled temperatures did however closely resemble temperature estimates based on NOAA satellite images (van der Veer et al. 2009, their Fig. 3). The cold winter in 1996, as reflected by coastal surface water temperatures, was not exceptionally cold in the NOAA temperature series or in the modelled temperatures. According to van der Veer \& Witte (1999), this is caused by a persistent plume of relatively warm English Channel water which enters the North Sea through the Dover Straight.

The large interannual variation in distance over which plaice eggs and larvae were transported implies that the connectivity between spawning and nursery areas may vary considerably between years. In some years, the majority of plaice larvae originating from the Southern Bight spawning ground settled in Dutch coastal and estuarine waters, whereas in other years the larvae were transported into the German Bight or even onto the Danish coast. This raises the question whether larvae that are transported to a distant nursery ground, which is normally populated by larvae from a nearer spawning ground, will return to their natal spawning ground or to the nearer spawning ground. If the latter is the case, then this may provide a mechanism that will smooth the spatial population structure by exchange of fish between spawning populations.

Years in which transport success was relatively high were expected to coincide with years of above average recruitment, but no significant relationship was found. We did observe a significant (negative) correlation between recruitment and displacement. This was also observed in herring (Dickey-Collas et al. 2009). The relationship between transport and recruitment may be caused by a breakdown in connectivity between spawning and nursery areas with increased transport rates. With the general direction of the residual currents, eggs and larvae will be transported along a continuous band of suitable nursery grounds along the continental coasts of the North Sea. This band continues along the Danish coast and extends well into the Kattegat and Skagerrak. However, eggs and larvae which are carried in the current from the Southern Bight in a northeasterly direction may not survive long enough to contribute to recruitment. If this is the case, then reaching a nursery area close to the spawning ground (retention) is of great importance for recruitment success, as indicated by the correlation between recruitment and displacement. However, the lack of a significant correlation between recruitment and transport success may also be caused by the fact that only the Southern Bight spawning ground was included in the interannual variability analyses. High transport rates may also affect the transport success of larvae that are born on other spawning grounds. Spawning in the Southern Bight will likely result in larvae reaching suitable nursery grounds despite large interannual variation in transport, whereas spawning in the Ger- 
man Bight or Dogger Bank region gives a higher risk of advective losses in years with high transport rates, based on the location of these spawning grounds in relation to the location of the nursery areas.

In North Sea plaice, year-class strength appears to be established in early life (Bannister et al. 1974, van der Veer 1986). Several authors have suggested an inverse relationship between seawater temperature during early life stages and subsequent year-class strength (e.g. van der Veer \& Witte 1999, Fox et al. 2000). Cold winters in the North Sea are associated with easterly winds instead of the prevailing westerly winds and this affects residual currents and hydrodynamic transport. This was clearly the case in 1996a cold winter (based on coastal water temperatures) with extremely low residual currents in northeasterly direction. Hydrodynamically driven variability in transport has been suggested to play a role in determining year-class strength in plaice (Nielsen et al. 1998, van der Veer et al. 1998) and other species (Werner et al. 1997, Wilderbuer et al. 2002). The present study provides evidence in support of this hypothesis: interannual variability in transport patterns, specifically the distance over which eggs and larvae are transported from spawning grounds to nursery areas, contributes to recruitment variability.

Acknowledgements. This study was commissioned in the Netherlands by the Port of Rotterdam and the National Institute for Coastal and Marine Management (RIKZ) as part of their research programme on the impact of the Maasvlakte 2 land reclamation on the ecology of the southern North Sea and the Wadden Sea. Thanks are due to Z. Jager, J. de Kok, M. van Ledden and H. F. J. Los for fruitful discussions during the project meetings. M. R. Heath and R. D. M. Nash are thanked for their advice and constructive comments during the development and execution of the study. M.D.C. was also partially funded through the EU project RECLAIM.

\section{LITERATURE CITED}

Apstein C (1909) Die bestimmung des Alters pelagisch lebender Fischeier. Mitt Dtsch Seefischver 25:364-373

Bannister RCA, Harding D, Lockwood SJ (1974) Larval mortality and subsequent year-class strength in the plaice (Pleuronectes platessa L.). In: Blaxter JHS (ed) The early life history of fish. Springer-Verlag, Berlin, p 21-37

Bergman MJN, van der Veer HW, Stam A, Zuidema D (1989) Transport mechanisms of larval plaice (Pleuronectes platessa L.) from the coastal zone into the Wadden Sea nursery area. Rapp P-V Reùn Cons Int Explor Mer 191: 43-59

Boehlert GW, Mundy BC (1988) Roles of behavioural and physical factors in larval and juvenile fish recruitment to estuarine nursery areas. Am Fish Soc Symp 3:51-67

Bolle LJ, Dickey-Collas M, Erftemeijer PLA, van Beek JKL and others (2005) Impacts of Maasvlakte 2 on the Wadden Sea and North Sea coastal zone. Track 1: detailed modelling research. Part IV: fish larvae. Baseline study MEP Maasvlakte 2. Lot 3b: fish larvae. RIVO Report
C072/05, RIVO-Netherlands Institute for Sea Research, IJmuiden. Available at www.verkeerenwaterstaat.nl/ kennisplein/page_kennisplein.aspx? DossierURI=tcm:195$17870-4 \& I d=325640$

Champalbert G, Koutsikopoulos C (1995) Behaviour, transport and recruitment of Bay of Biscay sole (Solea solea): laboratory and field studies. J Mar Biol Assoc UK 75: 93-108

Coombs SH, Nichols JH, Fosh CA (1990) Plaice eggs (Pleuronectes platessa L.) in the southern North Sea: abundance, spawning area, vertical distribution, and buoyancy. J Cons Int Explor Mer 47:133-139

Creutzberg F, Eltink ATGW, van Noort GJ (1978) The migration of plaice larvae Pleuronectes platessa into the western Wadden Sea. In: McLusky DS, Berry AJ (eds) Physiology and behaviour of marine organisms. Pergamon Press, Oxford, p 243-251

Cushing DH (1972) The production cycle and the numbers of marine fish. In: Edwards RW, Garrod DJ (eds) Conservation and productivity of natural waters. Pergamon Press, Oxford, p 213-232

Cushing DH (1990) Hydrographic containment of a spawning group of plaice in the Southern Bight of the North Sea. Mar Ecol Prog Ser 58:287-297

Dannevig H (1897) On the rearing of larval and post-larval stages of the plaice and other flat-fishes. 15th Annu Rep Fish Bd Scotl Pt III:175-192

de Graaf M, Jager Z, Vreugdenhil CB, Elorche M (2004) Numerical simulations of tidally cued vertical migrations of flatfish larvae in the North Sea. Estuar Coast Shelf Sci 59:295-305

> Dickey-Collas M, Fox CJ, Nash RDM, O'Brien CM (2003) Plaice egg mortality: Can we determine survivorship? J Sea Res 50:213-227

Dickey-Collas M, Bolle LJ, van Beek JKL, Erftemeijer PLA (2009) Variability in transport of fish eggs and larvae. II. Effects of hydrodynamics on the transport of Downs herring larvae. Mar Ecol Prog Ser 390:183-194

- Erftemeijer PLA, van Beek JKL, Bolle LJ, Dickey-Collas M, Los HFJ (2009) Variability in transport of fish eggs and larvae. I. Modelling the effects of coastal reclamation. Mar Ecol Prog Ser 390:167-181

> Fox CJ, Planque B, Darby CD (2000) Synchrony in the recruitment time-series of plaice (Pleuronectes platessa L.) around the United Kingdom and the influence of sea temperature. J Sea Res 44:159-168

> Fox CJ, Geffen AJ, Blyth R, Nash RDM (2003) Temperaturedependent development rates of plaice (Pleuronectes platessa L.) eggs from the Irish Sea. J Plankton Res 25: $1319-1329$

Fox CJ, McCloghrie P, Young EF, Nash RDM (2006) The importance of individual behaviour for successful settlement of juvenile plaice (Pleuronectes platessa L.): a modelling and field study in the eastern Irish Sea. Fish Oceanogr 15:301-313

Gibson RN (1973) The intertidal movements and distribution of young fish on a sandy beach with special reference to the plaice (Pleuronectes platessa L.). J Exp Mar Biol Ecol 12:79-102

Gibson RN, Robb L, Burrows MT, Ansell AD (1996) Tidal, diel and longer term changes in the distribution of fishes on a Scottish sandy beach. Mar Ecol Prog Ser 130:1-17

Gibson RN, Robb L, Wennhage H, Burrows MT (2002) Ontogenetic changes in depth distribution of juvenile flatfishes in relation to predation risk and temperature on a shallowwater nursery ground. Mar Ecol Prog Ser 229:233-244

Harding D, Nichols JH, Tungate DS (1978) The spawning of 
plaice (Pleuronectes platessa L.) in the southern North Sea and English Channel. Rapp P-V Reùn Cons Int Explor Mer 172:102-113

Heessen HJL, Rijnsdorp AD (1989) Investigations on egg production and mortality of cod (Gadus morhua L.) and plaice (Pleuronectes platessa L.) in the southern and eastern North Sea in 1987 and 1988. Rapp P-V Reùn Cons Int Explor Mer 191:15-20

Hovenkamp F (1991) On the growth of larval plaice in the North Sea. PhD thesis, State University of Groningen

Hyder K, Nash RDM (1998) Variations in settlement pattern of Irish Sea plaice (Pleuronectes platessa L.) as determined from a simulation model. J Sea Res 40:59-71

ICES (2006) Report of the working group on beam trawl surveys (WGBEAM), 16-19 May 2006, Hamburg, Germany. ICES CM 2006/LRC:11, ICES, Copenhagen

ICES (2008) Report of the working group on the assessment of demersal stocks in the North Sea and Skagerrak (WGNSSK) ICES CM 2008/ACOM:09, ICES, Copenhagen

Dager Z (1999) Selective tidal stream transport of flounder larvae (Platichthys flesus L.) in the Dollard (Ems estuary). Estuar Coast Shelf Sci 49:347-362

> Joordens JCA, Souza AJ, Visser A (2001) The influence of tidal straining and wind on suspended matter and phytoplankton distribution in the Rhine outflow region. Cont Shelf Res 21:301-325

Koutsikopoulos C, Fortier L, Gagne JA (1991) Cross shelf dispersion of Dover sole (Solea solea) eggs and larvae in Biscay Bay and recruitment to inshore nurseries. J Plankton Res 13:923-945

Leggett WC, Deblois E (1994) Recruitment in marine fishes: Is it regulated by starvation and predation in the egg and larval stages? Neth J Sea Res 32:119-134

Lesser GR, Roelvink JA, van Kester JATM, Stelling GS (2004) Development and validation of a three-dimensional morphological model. Coast Eng 51:883-915

Macquart-Moulin C, Castelbon C, Champalbert G, Chikhi D, Le Direach-Boursier L, Patriti G (1989) The role of barosensitivity in the control of migrations of larval and juvenile sole (Solea solea L.): influence of pressure variations on swimming activity and orientation. Rapp P-V Reùn Cons Int Explor Mer 191:400-408

Nash RDM, Geffen AJ (2000) The influence of nursery ground processes in the determination of year-class strength in juvenile plaice, Pleuronectes platessa L. in Port Erin Bay, Irish Sea. J Sea Res 44:101-110

> Nielsen E, Bagge O, MacKenzie BR (1998) Wind-induced transport of plaice (Pleuronectes platessa) early life-history stages in the Skagerrak-Kattegat. J Sea Res 39:11-28

Nolte A, van Beek JKL, Boderie P, Los HFJ (2005) Impacts of Maasvlakte 2 on the Wadden Sea and North Sea coastal zone. Track 1: detailed modelling research. Part III: nutrients and primary production. Tech Rep Z3945.40, WL I Delft Hydraulics, Delft

Pepin P (1991) Effect of temperature and size on development, mortality, and survival rates of pelagic early life history stages of marine fish. Can J Fish Aquat Sci 48: 503-518

Postma L (1988) DELWAQ users manual, version 3.0. WL I Delft Hydraulics, Delft

> Power JH, Burger MJ, Stokes AM (2007) Mass, volume, and length relationships in plaice (Pleuronectes platessa) juveniles. J Sea Res 57:230-235

Rauck G (1974) The arrival of different groups of young plaice in the German Wadden Sea. Ber Wiss Kommn Meeresforsch 23:273-288
Rijnsdorp AD, van Stralen M, van der Veer HW (1985) Selective tidal transport of North Sea plaice larvae Pleuronectes platessa in coastal nursery areas. Trans Am Fish Soc 114: $461-470$

Roelvink JA, Van Banning GKFM (1994) Design and development of DELFT3D and application to coastal morphodynamics. In: Verwey A, Minns AW, Babovic M, Maksimovic C (eds) Proc Hydroinformatics 1994. Balkema, Rotterdam, p 451-456

Roelvink JA, van der Kaaij T, Ruessink G (2001) Calibration and verification of large-scale 2D/3D flow models. MARE report, phase 1, sub-product 2. Tech Rep Z3029.11, WL I Delft Hydraulics, Delft

Russell FS (1976) The eggs and planktonic stages of British marine fishes. Academic Press, London

Ryland JS (1966) Observations on the development of larvae of the plaice, Pleuronectes platessa L., in aquaria. J Cons Int Explor Mer 30:177-195

Ryland JS, Nichols JH (1975) Effect of temperature on the embryonic development of the plaice, Pleuronectes platessa L. (Teleostei). J Exp Mar Biol Ecol 18:121-137

Stelling GS, van Kester TJA (1994) On the approximation of horizontal gradients in sigma coordinates for bathymetry with steep bottom slopes. Int J Numer Methods Fluids 18: 915-935

Sundby S (1991) Factors affecting the vertical distribution of eggs. ICES Mar Sci Symp 192:33-38

Talbot JW (1977) The dispersal of plaice eggs and larvae in the Southern Bight of the North Sea. J Cons Int Explor Mer 37:221-248

Taylor N, Fox CJ, Bolle LJ, Dicky-Collas M and others (2007) Results of the spring 2004 North Sea ichthyoplankton surveys. ICES Coop Res Rep No. 285, ICES, Copenhagen

Teal LR, de Leeuw JJ, van der Veer HW, Rijnsdorp AD (2008) Effects of climate change on growth of 0-group sole and plaice. Mar Ecol Prog Ser 358:219-230

van Beek FA, Rijnsdorp AD, de Clerk R (1989) Monitoring juvenile stocks of flatfish in the Wadden Sea and coastal areas of the southeastern North Sea. Helgol Wiss Meeresunters 43:461-477

van Damme CJG, Bolle LJ, Fox CJ, Fossum P and others (2009) A reanalysis of North Sea plaice spawning-stock biomass using the annual egg production method. ICES J Mar Sci 66:1999-2011

van der Land MA (1991) Distribution of flatfish eggs in the 1989 egg surveys in the south-eastern North Sea, and mortality of plaice and sole eggs. Neth J Sea Res 27:277-286

> van der Veer HW (1986) Immigration, settlement, and density-dependent mortality of a larval and early postlarval 0-group plaice (Pleuronectes platessa) population in the western Wadden Sea. Mar Ecol Prog Ser 29:223-236

van der Veer HW, Witte JIJ (1999) Year-class strength of plaice Pleuronectes platessa in the Southern Bight of the North Sea: a validation and analysis of the inverse relationship with winter seawater temperature. Mar Ecol Prog Ser 184:245-257

> van der Veer HW, Ruardij P, van der Berg AJ, Ridderinkhof H (1998) Impact of interannual variability in hydrodynamics circulation on egg and larval transport of plaice Pleuronectes platessa L. in the southern North Sea. J Sea Res 39: $29-40$

van der Veer HW, Geffen AJ, Witte JIJ (2000) Exceptionally strong year classes in plaice Pleuronectes platessa: Are they generated during the pelagic stage only, or also in the juvenile stage? Mar Ecol Prog Ser 199:255-262

van der Veer HW, Bolle LJ, Geffen AJ, Witte JIJ (2009) Variability in transport of fish eggs and larvae. IV. Interannual 
variability in larval stage duration of immigrating plaice in the Dutch Wadden Sea. Mar Ecol Prog Ser 390:213-223

- Werner FE, Quinlan JA, Blanton BO, Luettich RA Jr (1997) The role of hydrodynamics in explaining variability in fish populations. J Sea Res 37:195-212

Wilderbuer TK, Hollowed AB, Ingraham WJ, Spencer PD, Conners ME, Bond NA, Walters GE (2002) Flatfish recruit-

Editorial responsibility: Nicholas Tolimieri, Seattle, Washington, USA ment response to decadal climatic variability and ocean conditions in the eastern Bering Sea. Prog Oceanogr 55: $235-247$

Zijlstra JJ (1972) On the importance of the Wadden Sea as a nursery area in relation to the conservation of the southern North Sea fishery resources. Symp Zool Soc Lond 29: $233-258$

Submitted: December 19, 2008; Accepted: June 23, 2009 Proofs received from author(s): September 12, 2009 